\title{
U.S. Peach Producer Preference and Willingness to Pay for Fruit Attributes
}

\author{
Shuoli Zhao ${ }^{1}$ \\ Department of Applied Economics, University of Minnesota, Twin Cities, \\ 1994 Buford Avenue, St. Paul, MN 55108
}

Chengyan Yue ${ }^{2,8}$

Department of Horticultural Science and Department of Applied Economics, University of Minnesota, Twin Cities, 1970 Folwell Avenue, St. Paul, MN 55108

James Luby $^{3}$
Department of Horticultural Science, University of Minnesota, Twin Cities,
1970 Folwell Avenue, St. Paul, MN 55108

Karina Gallardo ${ }^{4}$

School of Economic Sciences, Puyallup Research and Extension Center, Center for Precision Agriculture and Automated Systems, Washington State University, 2606 West Pioneer, Puyallup, WA 98371

Vicki McCracken ${ }^{5}$

School of Economic Sciences, Washington State University, P.O. Box 646210, Hulbert Hall 101, Pullman, WA 99164

\section{James McFerson ${ }^{6}$}

Washington Tree Fruit Research Commission, 1719 Springwater Avenue, Wenatchee, WA 98801

Desmond R. Layne ${ }^{7}$

Department of Horticulture, Washington State University, P.O. Box 646414, Johnson Hall 149, Pullman, WA 99164

Additional index words. rosaceous fruits, marketing, farm size, production targets, choice experiments

\begin{abstract}
This study investigates U.S. peach producers' willingness to pay (WTP) for potential improvement of peach fruit attributes. Data were collected from 124 U.S. peach producers. The choice experiment and socioeconomic data were analyzed using mixed logit (ML) models to estimate the producer WTP and preferences for peach attributes. The results indicate that the WTP for attribute values vary across peach producers from different production regions (California and eastern United States), with different selling targets (fresh and processed) and different orchard sizes (smaller or larger than $\mathbf{1 5}$ acres). These results provide useful information for peach breeders in prioritizing traits in their breeding programs.
\end{abstract}

Peach [Prunus persica (L.) Batsch] is an important crop for both fresh and processed markets in worldwide. It is increasingly challenging for peach producers to select the ideal scion cultivar that satisfies market requirements and maximizes their profits, especially considering the high capital investment for establishment and time lag to generating a positive cash flow (Day et al., 2009; Yue et al., 2014). Total farm gate value of U.S. peach production was $\$ 606$ million in 2015 and used production was 825,415 tons, including 467,680 tons for processing (USDA NASS, 2016). Although commercial production is distributed across 23 states, California is the largest producer, accounting for $73 \%$ of total U.S. production in 2015 . Forty-eight percent of fresh peaches and $96 \%$ of processed peaches were produced in for canning (Gradziel and McCaa, 2008). In contrast, the fruit flesh of melting freestone peaches is easily separated from the pit and becomes increasingly soft and juicy during ripening (Okie et al., 2008). Nonmelting clingstone cultivars have been bred specifically for the processed market and are not typically for fresh consumption, whereas melting freestone cultivars have been bred specifically for the fresh market. However, when peaches are over supplied in the market, some melting freestone peaches may be processed by canning or freezing.

Different peach-growing regions differ significantly in production conditions, transportation, and marketing channels. Cultivars that were originally bred in California are highly susceptible to bacterial spot disease (Xanthomonas arboricola pv. pruni), a very serious disease in the wet and humid climate of the eastern United States (Ritchie et al., 2008), and can require weekly sprays of antibiotics to produce blemish-free fruit (Horton et al., 2003). California fresh market producers tend to have larger size operations compared with other peach-producing regions and primarily supply their fruit through commercial chain stores across the United States. Therefore, peaches from California need to be harvested before reaching full physiological maturity to permit the longdistance transportation. Fruit from the eastern United States are mostly harvested closer to maturity, especially for smaller-sized operations, which usually sell their peach to local grocery stores, farmers' markets, and roadside markets (Hardesty and Leff, 2010).

Peach producers must select the scion cultivar best suited to their specific environmental conditions and marketing channels (Fuglie and Walker, 2001). The choice of cultivars is a decision with high stakes for peach producers, given fluctuating market demands and the significant time lag to generate positive cash flow (Day et al., 2009). Choosing the cultivar with superior horticultural performance and market acceptance provides advantages to producers; other parties in the supply chain such as packers, shippers, and retailers; and ultimately, consumers. Dandekar and Iezzoni (2012) emphasized that new cultivars of rosaceous fruits play a vital role to improve fruit quality, increase producer production and consumer consumption, increase fruit competitiveness, and enhance the profit of every stakeholder (i.e., producers, processors, shippers, packers, retailers, and brokers) along the supply chain.

Significant financial inputs and labor resources are generally required to develop and commercialize new cultivars. Breeders typically have a sense of the importance of certain fruit traits based on their informal contacts with stakeholders, but the marginal values of these traits are unknown (Gallardo et al., 2012). For example, a common perception among peach breeders is that external fruit color is critical for a new fresh peach cultivar, but the marginal value for the improvement of external color from not 
desirable (lack of skin blush/color) to desirable (cream/yellow background color with a red blush) remains unknown. Nonetheless, it is producers who take the risk of investing in growing a cultivar they hope will have consumer acceptance throughout the supply chain. Since producers are the direct clientele of breeding programs, their perceptions and valuations of fruit attributes provide essential information in setting peach breeding targets. Combining this input with that from other parties in the supply chain, breeders could significantly improve efficiency of their programs and the commercial success of their releases (Yue et al., 2012).

Most relevant empirical research has focused on consumer preference analysis for peach fruit attributes. Jordan et al. (1986) and Parker et al. (1991) indicated that U.S. fresh peach prices are positively correlated with fruit attributes, including freedom from defects, color, maturity, and size. Ravaglia et al. (1966) found that a high level of soluble solids content (SSC) is also important for consumer acceptance. Hilaire (2003) further established that a minimum of $10 \% \mathrm{SSC}$ is needed for peaches with low titratable acidity and $11 \%$ SSC for peaches with high titratable acidity, to achieve consumers' overall acceptability. Crisosto (2005) concluded that the ratio of SSC and titratable acidity levels for desirable fruit varies across peach cultivars, whereas Predieri et al. (2006) found that titratable acidity, astringency, and sweetness were positively correlated with overall appreciation of 'Royal Gem' (yellow peach) and 'Silver Rome' (white peach).

Consumers' preferences for fruit attributes have significant impacts on producers' adoption of peach scion cultivars, but the attributes preferred by consumers may not generate the maximum profit for producers. For growers, cultivars with different attributes have different yield rates, and need different levels of inputs (labor, fertilizers, pesticides, etc.) and thus different production/storage/handling costs. These factors would affect growers' willingness to invest in new cultivars with improved attributes. Furthermore, while most businesses such as food retailers and processors would be interested in evaluating consumer preferences

Received for publication 23 May 2016. Accepted for publication 2 Aug. 2016.

This research was funded by the USDA National Institute of Food and Agriculture Specialty Crop Research Initiative project "RosBREED: Enabling marker-assisted breeding in Rosaceae" (2009-51181-05808).

${ }^{1} \mathrm{PhD}$ Student.

${ }^{2}$ Associate Professor and Bachman Endowed Chair in Horticultural Marketing.

${ }^{3}$ Professor.

${ }^{4}$ Associate Professor and Extension Specialist.

${ }^{5}$ Professor and Associate Director of Agricultural Research Center.

${ }^{6}$ Manager.

${ }^{7}$ Professor and Director of Agricultural and Food Systems and Integrated Plant Sciences degree programs.

${ }^{8}$ Corresponding author. E-mail: yuechy@umn.edu. for a new product or attribute, agribusinesses such as seed and chemical companies, technology, and equipment dealers, and agricultural service providers might be interested in assessing producer WTP for a new cultivar (Lusk and Hudson, 2004). In contrast to the literature investigating consumers' preferences and WTP for peach attributes, very few studies have focused on peach producers' preferences for peach attributes. Yue et al. (2014) conducted audience surveys at grower meetings to investigate peach growers' perception of the relative importance of peach attributes finding that fresh peach growers in the eastern United States consider fruit flavor and fruit size as the most important traits, whereas processed peach growers in California regard size, absence of spit pits, and firmness as the most important traits.

Although Yue et al. (2014) estimated peach producers' relative importance of the plant and fruit quality traits based on ranking attributes, this study elicited growers' WTP for fruit traits using choice experiments. In importance ranking questions, participants often do not consider the cost associated with their preferred attributes, which could affect the ranking. Choice experiments are designed to overcome this issue through the inclusion of costs in the choice sets. As a result, information is obtained for both the relative importance of the fruit traits and the producers' WTP values for trait improvement. Further, the study conducted by Yue et al. (2014) was based on a state or regional sample at grower meetings. In contrast, this study is based on a random sample of growers from the top five producing states across the United States. To our knowledge, after Park and Florkowski (2003) studied the relative importance of peach attributes for Georgia producers over a decade ago, no other study has focused on peach producers' WTP for fruit attribute improvement, and we aim to fill this knowledge gap.

Specifically, in this study, we investigate producers' WTP for peach fruit attributes and explore the potential producer segments by region, farm size, and use of final products (fresh vs. processed). The information can help peach breeders prioritize fruit traits in their breeding programs to increase their efficiency and the commercial success of their releases.

\section{Survey Design and Data}

Survey data were collected between February and June in 2012 using a combination of mail-in and internet survey methods. There were 3877 peach farms in the top five producing states (California, South Carolina, Georgia, New Jersey, and Pennsylvania) in 2012 (Vilsack and Clark, 2014). Due to budget constraint, we only sent surveys to a sample of the population instead of the whole population. We stratified our sample by states and selected our initial sample size based on the number of peach orchards in these sampled states. Then for each state, the orchards were randomly selected from a comprehensive producer list provided by Meister
Media Inc., a trade magazine whose primary clientele are U.S. fruit growers.

The Dillman total design method protocol-survey, then reminder card, and then survey-was employed to increase response rate (Dillman et al., 2009). The survey package included a cover letter, a booklet questionnaire, postage-paid return envelope, and a $\$ 4$ preincentive. The e-mail included the survey URL and a personal access code. The cover letter explained the purpose of the study, provided the general information about the project, and addressed the concerns that producers might have regarding the confidentiality of their responses. The total number of surveys sent out to California peach producers was 229 and 48 were completed ( $21 \%$ response rate); for non-California producers, 224 surveys were sent out and 76 were completed (34\% response rate).

There were five sections in our survey. The first section was called "About Your Farm," and included choice questions and rating questions pertaining to producers' main target of production, importance of market factors such as transportation cost, and available sales channels. Part two was called "Fruit and Plant Attributes," included Likert scale rating and best-worst questions about producers' preferences for certain fruit and tree attributes, and choice experiment questions. Part three was "Adoption of New Varieties," which included questions related to factors that impact producers' new variety acceptance. Part Four was "Information about Your Farm Operation." This section focused on farm information such as total acreage, location, business structure, and gross income. The final section was "Information about You" including producers' gender, age, years of experience, racial background, and educational background.

For the choice experiment questions, participants were presented with a series of scenarios and asked to choose one alternative to produce in each scenario. To lessen the cognitive burden on participants in the choice experiment, only two alternatives were included in each scenario. Participants were also given the option to mark "Neither" for each scenario, indicating they would not produce either alternative. In the scenarios, each of the two alternatives was characterized by a combination of attributes including external appearance, external color, firmness and taste, sweetness, and production cost. We explicitly included only fruit attributes in the choice experiments, and excluded tree traits, because a major socioeconomic objective of the RosBREED project, in which this research was conducted, is to compare the preferences and WTP for rosaceous fruit traits among growers, market intermediaries (e.g., shippers, packers, and marketers), and consumers. Further, market intermediaries and consumers are less likely to care about tree traits. Therefore, to compare the three parties' preferences and WTPs on the same basis, we only included the major fruit traits that are considered as important by all three parties in the discrete choice questions. Since 
it was not practical to ask each participant to choose from all possible scenarios, a fractional factorial design was developed to minimize scenario number and maximize profile variation. The choice scenarios were designed using $\mathrm{JMP}^{\circledR} 8$ software (SAS Institute Inc., Cary, NC).

For the details of the peach fruit attribute and attribute levels included in the choice experiment, please refer to Table 1 . The attributes were selected by consulting with peach industry experts and interviewing individual peach producers. The choice experiment was designed to mimic a typical production situation by providing the essential attribute information that a producer would normally face when they decide which cultivars to grow. An example of the choice scenarios is shown in Table 2.

\section{Methodology}

Discrete choice models describe decision makers' choices between different alternatives and are widely used by researchers to estimate an individual's WTP. Although choice experiments are often discussed within the context of utility maximization of consumers, this concept can also be extended to producers (Lusk and Hudson, 2004).

Logit models are recognized as the essential tool kit for study discrete choices (Hensher and Greene, 2003) and the multinomial (or conditional) logit model (MNL) has been the standard techniques for discrete choice analysis for over 30 years. However, some have questioned the restrictiveness of the independence of irrelevant alternatives (IIAs) assumption and have developed a variety of alternative models that generalize the MNL (Chang and Lusk, 2011). One such model is the ML, which relaxes the IIA assumption by modeling preference hetero- geneity, and can approximate any underlying random utility function.

We assume producers choose the alternative that maximizes their perceived profit from a choice set. Suppose a choice set has $M$ alternatives $(j=1,2, \ldots, M)$. For producer $i$ $(i=1,2, \ldots, N)$, the perceived profit derived from choosing the $j$ th alternative can be represented as follows:

$$
\Pi_{i j}=\beta x_{i j}+\gamma_{i} z_{i}+\varepsilon_{i j}
$$

where $\Pi_{i j}$ is the perceived profit of producer $i$ from choosing alternative $j ; x_{i j}$ are the observed peach quality attributes in alternative $j$ presented to producer $i ; z_{i}$ are the observed variables relating to producer $i ; \beta$ is a vector of fixed coefficients depicting the marginal profit derived from each peach quality attribute; $\gamma$ is a vector of random coefficients that are assumed to follow a normal distribution; and $\varepsilon_{i j}$ is an identical and independent error term that follows extreme value distribution.

Suppose the density function of $\gamma_{i}$ is $f\left(\gamma_{i} \mid \Omega\right)$, where $\Omega$ is a vector of fixed parameter of the normal distribution, then for a given $\gamma_{i}$, the conditional probability of choosing alternative $j$ is as follows:

$$
L_{i}\left(j \mid \gamma_{i}\right)=\frac{e^{\beta x_{i j}+\gamma_{i} z_{i j}}}{\sum_{k=1}^{M} e^{\beta x_{i k}+\gamma_{i} z_{i k}}}
$$

Since $\gamma_{i}$ is not given, the unconditional choice likelihood of individual $i$ choosing alternative $j$ is obtained by integrating the conditional probability overall possible values of $\gamma_{i j}$ :

$$
\begin{aligned}
& \operatorname{Pr}\left(Y_{i}=j\right) \\
& \quad=\int \frac{\exp \left(\beta x_{i j}+\gamma_{i} z_{i j}\right)}{\sum_{k=1}^{M} \exp \left(\beta x_{i k}+\gamma_{i} z_{i k}\right)} f\left(\gamma_{i j} \mid \Omega\right)
\end{aligned}
$$

Based on the estimation of the ML models, the WTP value of a certain attribute improvement from one level to another is referred to as the marginal rate of substitution between the attribute and the price, and is calculated by dividing the marginal utility of each attribute by the marginal utility of price (multiplied by -1 ).

\section{Results and Discussion}

As the summary statistics of survey respondents illustrate in Table 3, most are male, Caucasian, have completed at least a 4-year college degree with an average age of 55 years, and have an average of 26 years' experience in peach production. About half of the respondents' peach orchards are operated by a family or an individual and half are covered by some type of insurance. Average peach orchard size differs between production regions. Thirteen percent of orchards in California are smaller than 15 acres, whereas $37 \%$ of peach orchards outside of California are smaller than 15 acres. About $97 \%$ of producers outside of California are targeting their peach crop to the fresh market, whereas $62 \%$ of producers in California target the fresh market. Ninety-six percent of producer respondents outside of California listed "directly to consumers" as one of their selling channels, whereas only $31 \%$ of California producers sell directly to consumers.

The WTP values were calculated based on the parameter estimates of the ML model. In the following sections, we compare WTP difference based on the producers' geographic regions, target market, and size of the operation.

Regional difference: Comparison between fresh producers in California and outside of California. Peaches are mainly produced in either the western (California) or eastern (southeast and mid-Atlantic) United States. Due to the significant regional differences in key factors (climate, soil, production

\begin{tabular}{|c|c|c|c|}
\hline Attribute & Option A & Option B & Option C \\
\hline External color & $\begin{array}{l}\text { Desirable (cream/yellow background } \\
\text { color with a red blush color) }\end{array}$ & Not desirable (lack of skin blush/color) & Neither option \\
\hline Size & Size 50 and larger & Size 80 to 56 & \\
\hline External appearance: free of defects & Fair $(<70 \%$ packout $)$ & Good ( $>85 \%$ packout) & \\
\hline $\begin{array}{l}\text { Flavor (combination of sweetness, } \\
\text { sweet/tart balance and aroma) }\end{array}$ & Full/intense flavor & Weak/mild flavor & \\
\hline Sweetness (soluble solids) & Low (less than $11^{\circ}$ Brix) & High (more than $11^{\circ}$ Brix) & \\
\hline
\end{tabular}

Table 1. Attribute levels for choice experiment questions used in the peach producer survey collected in 2012.



Table 2. Choice experiment scenario example from California peach producers survey collected in 2012. 
systems, and target markets), we hypothesized producers from different regions would have different WTP for peach attributes.

Table 4 shows the ML estimation results and California and non-California producer WTP values for fresh peach fruit attributes. For producers in California, flavor is the most important attribute, and they are willing to pay $\$ 0.277 / \mathrm{lb}$ to enhance fruit flavor. Following flavor, producers are willing to pay a premium of $\$ 0.222 / \mathrm{lb}$ and $\$ 0.214 / \mathrm{lb}$ for external color and external appearance, respectively. Flavor is commonly recognized as the major disadvantage for California fresh peaches compared with eastern grown fresh peaches. California producers deliver fruit through a longer market chain that may involve market intermediaries such as wholesalers and distributors. Their fruit require one to three additional days of transportation to reach final markets in midwestern and eastern North America compared with eastern U.S. producers. Specifically, many eastern producers directly market fruit to consumers at their farms or farmers' markets and can pick fruits just before full maturity and full flavor development (Crisosto, 2002). This relatively greater distance from many retail markets generally necessitates that California producers harvest fruit at a more immature stage. Thus, their product often lacks desirable external fruit color and arrives at point of sale with diminished fruit flavor. Larger fruit size, as key determinant for higher market price, is also preferred by California producers, with a WTP value of $\$ 0.190 / 1 b$. In addition to this price advantage, fresh California peaches with larger size also provide greater efficiency in harvesting since larger size indirectly increases the total weight of fruit picked per hour of harvest labor.

Fresh peach producers outside of California are willing to pay the most $(\$ 0.458 / \mathrm{lb})$ for the enhancement of fruit flavor, followed by the WTP values for external color $(\$ 0.395 / \mathrm{lb})$ and size $(\$ 0.336 / \mathrm{lb})$. Firmness improvement from less than $10 \mathrm{lb}$ to more than $10 \mathrm{lb}$ is the least important attribute to non-California producers. Since eastern producers can wait until almost full fruit maturity before harvesting and thus can more easily deliver a product with higher fruit quality, it is no surprise that they have a high WTP for flavor attribute (combination of sweetness, sweet/tart balance, and aroma). Meanwhile, external color is a comparative lacking attribute for fresh non-California peaches. Most of the cultivars with solid red color on market are bred to be grown in California where the climate is dry, and those cultivars cannot be suitably grown in the eastern region due to their susceptibility to diseases in humid climates, such as bacterial spot disease. This supports external appearance as the second most important fruit attribute that non-California producers are willing to pay a premium price to improve.

Fresh and processed peach markets: Comparison between producers in California with different production target. Because California peach producers produce nearly all of the processed peaches in the United States, it is possible to compare WTP results of fresh and processed peach producers within a single state (Table 5). Nearly, 77\% of the California processed peach crop is canned (Plattner et al., 2013) and growers

Table 3. Summary statistics of producer respondents' demographic variables from peach producer survey data collected in $2012(\mathrm{n}=124)$.

\begin{tabular}{|c|c|c|c|}
\hline \multirow[b]{2}{*}{ Variable } & \multirow[b]{2}{*}{ Variable description } & \multicolumn{2}{|c|}{ Mean or proportion (SD) } \\
\hline & & $\begin{array}{l}\text { Producers in } \\
\text { California }\end{array}$ & $\begin{array}{l}\text { Producers not in } \\
\text { California }\end{array}$ \\
\hline$\overline{\text { Age }}$ & Respondent's age & $52.000(13.957)$ & $56.918(12.729)$ \\
\hline Gender & 1 if male; 0 if female & $0.956(0.208)$ & $0.959(0.199)$ \\
\hline Racial & 1 if Caucasian or white; 0 otherwise & $0.688(0.468)$ & $0.961(0.196)$ \\
\hline Edulow & 1 if the respondent has high school diploma or less; 0 otherwise & $0.091(0.291)$ & $0.400(0.493)$ \\
\hline Farm operation & $\begin{array}{l}1 \text { if family or individual operation (excluding partnerships and corporations); } \\
0 \text { otherwise }\end{array}$ & $0.545(0.504)$ & $0.541(0.502)$ \\
\hline Sizsmall & 1 if the total farm size is less than 5 acres; 0 otherwise & $0.106(0.312)$ & $0.205(0.407)$ \\
\hline Sizmedium & 1 if the total farm size is between 5 and 49 acres; 0 otherwise & $0.511(0.505)$ & $0.521(0.503)$ \\
\hline Sizemedlarge & 1 if the farm size is between 50 and 499 acres; 0 otherwise & $0.298(0.462)$ & $0.205(0.407)$ \\
\hline Sizelarge & 1 if the total farm size is larger than 500 acres; 0 otherwise & $0.085(0.282)$ & $0.068(0.254)$ \\
\hline Interestnew & 1 if interested in producing fruit with new or novel fruit attributes; 0 otherwise & $0.452(0.504)$ & $0.299(0.461)$ \\
\hline Otherfunc & $\begin{array}{l}1 \text { if perform other functions such as packing, shipping, or processing in addition } \\
\text { to production; } 0 \text { otherwise }\end{array}$ & $0.354(0.483)$ & $0.446(0.500)$ \\
\hline Number of respondents & & 48 & 76 \\
\hline
\end{tabular}

Table 4. ML model estimation results and WTP values of fresh peach producers in California and not in California based on peach producer survey data collected in 2012 .

\begin{tabular}{|c|c|c|c|c|}
\hline \multirow[b]{2}{*}{ Variable } & \multicolumn{2}{|c|}{ Coefficient (SE) } & \multicolumn{2}{|c|}{ WTP value $(\$ / 1 \mathrm{lb})$} \\
\hline & $\begin{array}{c}\text { Fresh peach producers } \\
\text { in California }\end{array}$ & $\begin{array}{c}\text { Fresh peach producers } \\
\text { not in California }\end{array}$ & $\begin{array}{l}\text { Fresh peach producers } \\
\text { in California }\end{array}$ & $\begin{array}{l}\text { Fresh peach producers } \\
\text { not in California }\end{array}$ \\
\hline$\overline{\text { Cost }}$ & $-0.153 * *(0.055)$ & $-0.115 *(0.058)$ & - & - \\
\hline Size & $0.725 * *(0.255)$ & $0.965 * * *(0.230)$ & 0.190 & 0.336 \\
\hline External appearance & $0.819 * *(0.290)$ & $0.553 *(0.224)$ & 0.214 & 0.193 \\
\hline Firmness & $-0.197(0.297)$ & $0.233(0.294)$ & - & - \\
\hline Flavor & $1.059 *(0.488)$ & $1.318 * *(0.466)$ & 0.277 & 0.458 \\
\hline
\end{tabular}

$\mathrm{WTP}=$ willingness to pay.

$*^{* *}, * * *$ Significant at $\alpha=0.05,0.01$, and 0.001 , respectively. Demographic variables included in the final models are ethical/racial background and education level for both producers in California and outside of California. 
are paid based on total production by weight. Thus, it is not surprising that the highest WTP of any fruit attribute was $\$ 0.738 / \mathrm{lb}$ for improved fruit external appearance (freedom from defects). This is likely directly related to their goal of maximizing total useable yield, since blemished fruit is culled. WTP for sweetness and size are statistically insignificant. This is not surprising, as canned peaches are packed in a sugar syrup, which can be adjusted easily to compensate for fruit lacking sufficient natural sweetness. Neither do growers receive a premium for individual fruit size. Similarly, firmness in a processed peach is not a major contributor to usable yield, and its WTP was barely significant. WTP for external color was found to be the second highest WTP at $\$ 0.386 / \mathrm{lb}$. High levels of red color due to anthocyanins, which bleed into the flesh during processing can cause oxidation and an unattractive brown color in the finished product, so that uniformly yellow-colored fruit are desirable. Interestingly, at $\$ 0.344 / \mathrm{lb}$, flavor showed the third highest WTP. Even though fresh peach producers in California indicated their most desirable fruit attribute was flavor, their WTP was only $\$ 0.277 / \mathrm{lb}$ indicated by fresh peach producers. Fresh peach producers value both higher external red color and external appearance at about the same WTP level (\$0.277/lb and 0.222/lb, respectively). Fruit size and to a lesser extent fruit sweetness were considered desirable with WTP levels of $\$ 0.190$ and $0.159 / \mathrm{lb}$, respectively. Finally, firmer fruit, from less than $10 \mathrm{lb}$ to more than $10 \mathrm{lb}$, did not elicit a significant WTP. Clearly, the WTP values for producers in California of these two distinct peach products require a breeding program to select among different and sometimes divergent trait priorities.

Small producers and large producers: How non-California producer's preferences vary with their orchard size. Peach production in California is highly concentrated and dominated by large-scale producers. In the eastern United States, most peach producers manage small- to medium-scale operations, using the metric suggested by MacDonald et al. (2013) that midacreage of peach operations in 2007 was 120 acres. All of the survey respondents outside of California were fresh peach producers, nearly $40 \%$ of them reported that they manage less than 15 acres, and more than $80 \%$ less than 100 acres. Different scales of production are often associated with different selling channels, so it is not surprising producers of contrasting scales may indicate contrasting preferences for peach fruit attributes (Table 6).

Overall, it is evident that smaller-scale producers outside of California are willing to pay for relatively few fruit attributes. Even those found significant (flavor, external color, and sweetness) had WTP levels much lower than any of the five attributes identified for larger scale producers (size, flavor, external color, sweetness, and external appearance). Producers who manage more than 15 acres of orchard are willing to pay the highest premium, $\$ 0.767 / \mathrm{lb}$, to improve fruit size from "Quarters" (2.25-inch diameter and up to 2.5 inches) to "Three-Quarters" (2.75-inch diameter and up to 3 inches). Fruit size is known as a critical attribute for wholesale packing, shipping, and marketing of fresh fruit. Larger scale producers in both California and the eastern United States mainly sell their products through brokers, retailers, and supercenters, so threshold market standards favor larger fruit size. In contrast, in many selling channels in the eastern region such as farmers market, U-pick and Community Supported Agriculture, flavor is often a determinant of consumer preference $(\$ 0.204$ / lb), and blemish-free, large-sized fruit do not command a certain price premium. However, larger scale operations in the eastern United States generally sell through channels where higher red external color and external freedom from defects are an advantage. Larger scale products shipping outside their local area in the eastern United States, just like California, often need to pick peaches at a less mature stage to reduce the risk of possible appearance damage during the transportation and marketing process and to retail, as opposed to smaller scale producers who can often harvest fruit closer to physiological maturity and still deliver a desirable product to consumers who are located close to the production area.

\section{Conclusion}

Peach producers across U.S. production regions have differentiated requirements and preferences for peach fruit attributes. To improve the overall sustainability and stability of the U.S. peach market, it is important for peach breeders to understand producers' preferences and WTP for peach attributes.

Table 5. ML model estimation results and WTP values of fresh peach producers and processed peach producers in California based on peach producer survey data collected in 2012.

\begin{tabular}{|c|c|c|c|c|}
\hline Variable & \multicolumn{2}{|c|}{ Coefficient (SE) } & \multicolumn{2}{|c|}{ WTP (\$/lb) } \\
\hline$\overline{\text { Cost }}$ & $-0.153^{* *}(0.055)$ & $-0.098^{* *}(0.031)$ & - & - \\
\hline External color & $0.849 *(0.345)$ & $0.946 * *(0.343)$ & 0.222 & 0.386 \\
\hline External appearance & $0.819 * *(0.290)$ & $1.809 * * *(0.469)$ & 0.214 & 0.738 \\
\hline Firmness & $-0.197(0.297)$ & $0.608 *(0.285)$ & - & 0.034 \\
\hline Flavor & $1.059 *(0.488)$ & $0.843 * *(0.315)$ & 0.277 & 0.344 \\
\hline
\end{tabular}

$\mathrm{WTP}=$ willingness to pay.

$*, * *, * *$ Significant at $\alpha=0.05,0.01$, and 0.001 , respectively. Demographic variables of ethical/racial background and education level have been included in the model for fresh producers in California.

Table 6. ML logit model estimation results and WTP values of small and large peach producers outside of California based on peach producer survey data collected in 2012 .

\begin{tabular}{|c|c|c|c|c|}
\hline \multirow[b]{2}{*}{ Variable } & \multicolumn{2}{|c|}{ Coefficient $(\mathrm{sE})$} & \multicolumn{2}{|c|}{ WTP $(\$ / l b)$} \\
\hline & $\begin{array}{c}\text { Producers whose orchards are } \\
\text { smaller than } 15 \text { acres }\end{array}$ & $\begin{array}{c}\text { Producers whose orchards are } \\
\text { larger than } 15 \text { acres }\end{array}$ & $\begin{array}{l}\text { Producers whose orchards are } \\
\text { smaller than } 15 \text { acres }\end{array}$ & $\begin{array}{c}\text { Producers whose orchards } \\
\text { are larger than } 15 \text { acres }\end{array}$ \\
\hline$\overline{\text { Cost }}$ & $-0.243 * * *(0.058)$ & $-0.071 *(0.029)$ & - & - \\
\hline Size & $0.169(0.216)$ & $1.362 * * *(0.274)$ & - & 0.767 \\
\hline External appearance & $0.914(0.339)$ & $0.508 * *(0.194)$ & - & 0.286 \\
\hline Firmness & $0.387(0.260)$ & $0.222(0.187)$ & - & - \\
\hline Flavor & $1.241 * *(0.432)$ & $0.993 * *(0.316)$ & 0.204 & 0.559 \\
\hline
\end{tabular}

$\mathrm{WTP}=$ willingness to pay.

$*, * *, * *$ Significant at $\alpha=0.05,0.01$, and 0.001 levels, respectively. Demographic variables included in the final models are business structure for large producers, gross income and education level for small producers. 
Our study compares the WTP for peach attributes by producers from California and non-California regions, mainly the southeastern United States. Within California, we compared different selling targets (fresh vs. processed), and in states other than California, we compared across different orchard sizes. On average, fresh peach producers in the eastern United States are willing to pay a premium for an improvement in flavor, while desiring enhancements in color and size. Processed peach producers consider the improvement of external appearance as very valuable, but the improvements in sweetness and size are not as important. We also found producers in eastern United States having less than 15 acres of orchards regard the improvement in size, external appearance, and flavor as more important compared with producers with larger orchard sizes, but were unwilling to pay large premiums for these improvements.

By recognizing peach producers' production region, target market, and orchard size, results of our study can assist peach breeding programs to map out individualized plans for peach cultivar development to contribute to the long-term peach market sustainability.

This study is a part of the transdisciplinary RosBREED project funded by the Specialty Crop Research Initiative, U.S. Department of Agriculture. RosBREED aims to increase the efficiency of the rosaceous breeding programs and increase the probability that successful varieties will be released by enabling the use of marker-assisted breeding. Further research could emphasize synthesis of the WTP values for peach attributes from all parties in the supply chain (producers, marketing intermediaries, and consumers), which combines both supply and demand analysis, to inform peach breeding decisions.

\section{Literature Cited}

Chang, J.B. and J.L. Lusk. 2011. Mixed logit models: Accuracy and software choice. J. Appl. Econ. 26:167-172.

Crisosto, C.H. 2002. How do we increase peach consumption? Acta Hort. 592:601-605.

Crisosto, C.H. 2005. Peach quality and postharvest technology. VI International Peach Symposium 713. p. 479-488.

Dandekar, A. and A. Iezzoni. 2012. The United States rosaceae genomics, genetics and breeding initiative. 23 Aug. 2015. <http://www.rosaceae.org/>.
Day, K.R., K.M. Klonsky, and R.L. De Moura. 2009. Sample costs to establish and produce peaches. University of California Cooperative Extension. 10 Jan. 2016. <http://coststudyfiles.ucdavis.edu/ uploads/cs_public/90/2f/902faeaa-5024-413d92dd-927002909580/peachesvs09.pdf>.

Dillman, D., J.D. Smyth, and L.M. Christian. 2009. Internet, mail and mixed-mode surveys: the tailored design method. John Wiley, New York.

Fuglie, K.O. and T.S. Walker. 2001. Economic incentives and resource allocation in US public and private plant breeding. J. Agr. Appl. Econ. 33(3):459-474.

Gallardo, R.K., K. Nguyen, V. McCracken, C. Yue, J. Luby, and J.R. McFerson. 2012. An investigation of trait prioritization in rosaceous fruit breeding programs. HortScience 47:771-776.

Gradziel, T.M. and J.P. McCaa. 2008. Processing peach cultivar development, p. 175-192. In: D.R. Layne and D. Bassi (eds.). The peach: Botany, production and uses. CAB International, Wallingford, Oxfordshire, UK.

Hardesty, S.D. and P. Leff. 2010. Determining marketing costs and returns in alternative marketing channels. Renewable Agr. Food Systems 25(1):24-34.

Hensher, D.A. and W.H. Greene. 2003. The mixed logit model: The state of practice. Transportation 30:133-176.

Hilaire, C. 2003. The peach industry in France: State of art, research and development, p. 2734. In: F. Marra and F. Sottile (eds.). Proc. First Mediterranean Peach Symp., Agrigento, Italy.

Horton, D., B. Bellinger, G. Pettis, P. Brannen, and W. Mitchem. 2003. Pest management strategic plan for eastern peaches. USDA-ARS/CSREES 10 Aug. 2015. <http://www.ipmcenters.org/ pmsp/pdf/EastPeach.pdfs.

Jordan, J.L., R.L. Shewfelt, and S.E. Prussia. 1986. The value of peach quality characteristics in the postharvest system. IX Symposium on Horticultural Economics. 203:175-182.

Lusk, J.L. and D. Hudson. 2004. Willingness-to-pay estimates and their relevance to agribusiness decision making. Rev. Agr. Econ. 26:152-169.

MacDonald, J.M., P. Korb, and R.A. Hoppe. 2013. Farm size and the organization of U.S. crop farming. U.S. Department of Agriculture, Economics Research Report No. 152, Washington, DC. 12 July 2016. <https://www.ers.usda.gov/ webdocs/publications/err152/39359_err152.pdfs.

Okie, W., T. Bacon, and D. Bassi. 2008. Fresh market cultivar development, p. 139-174. In: D.R. Layne and D. Bassi (eds.). The peach: Botany, production and uses. CAB International, Wallingford, Oxfordshire, UK.
Park, T.A. and W.J. Florkowski. 2003. Selection of peach varieties and the role of quality attributes. J. Agr. Resource Econ. 28(1):138-151.

Parker, D.D., D. Zilberman, and K. Moulton. 1991. How quality relates to price in California fresh peaches. Calif. Agr. 45:14-16.

Plattner, K., A. Perez, and D.W.R.U. Warm. 2013. Fruit and tree nuts outlook. United States Department of Agriculture, Economic Research Service report FTS-354. 30 Jan. 2016. <http:// www.ers.usda.gov/media/970458/fts354.pdf $>$.

Predieri, S., P. Ragazzini, and P. Rondelli. 2006. Sensory evaluation and peach fruit quality. Acta Horticulturae. VI International Peach Symposium, Santiago Chile, 30 July 2006. p. 429-434.

Ravaglia, G., S. Sansavini, M. Ventura, and D. Tabanelli. 1966. Indici di Maturazione e Miglioramiento Qualitative delle Pesche. Fruitcoltora. 3:61-66.

Ritchie, D., M. Barba, and M.C. Pagani. 2008. Diseases caused By prokaryotes - Bacteria and phytoplasmas, p. 407-434. In D.R. Layne and D. Bassi (eds.). The peach: Botany, production and uses. $\mathrm{CAB}$ International, Wallingford, Oxfordshire, UK.

United State Department of Agriculture, National Agricultural Statistics Service (USDA NASS) 2013. Noncitrus fruits and nuts 2012 preliminary summary. 17 Aug. 2015. <http://usda.mannlib. cornell.edu/usda/nass/NoncFruiNu//2010s/2013/ NoncFruiNu-01-25-2013.pdf>.

United State Department of Agriculture, National Agricultural Statistics Service. (USDA NASS). 2016. Noncitrus fruits and nuts 2015 preliminary summary. 13 July $2016 .<$ http:// usda.mannlib.cornell.edu/usda/current/NoncFruiNu/ NoncFruiNu-07-06-2016.pdfs.

Vilsack, T. and C.Z.F. Clark. 2014. 2012 census of agriculture. United States Department of Agriculture, Summary and State Data AC-12-A-51. 13 July 2016. <www.agcensus.usda.gov/ Publications/2012/Full_Report/Volume_1_ Chapter_1_US/usv1.pdf $>$.

Yue, C., R.K. Gallardo, J. Luby, A.L. Rihn, J.R. McFerson, V. McCracken, T. Gradziel, K. Gasic, G.L. Reighard, J. Clark, and A. Iezzoni. 2014. An evaluation of US peach producers' trait prioritization: Evidence from audience surveys. HortScience 49:13091314.

Yue, C.Y., R.K. Gallardo, V.A. McCracken, J. Luby, J.R. McFerson, L. Liu, and A. Iezzoni. 2012. Technical and socioeconomic challenges to setting and implementing priorities in North American rosaceous fruit breeding programs. HortScience 47:13201327. 